\title{
HUMORAL IMMUNE RESPONSE TO PORPHYROMONAS GINGIVALIS IN POSTPARTUM WOMEN AND NEWBORNS
}

\author{
Soraya Castro Trindade*, Isaac Suzart Gomes-Filho**, Simone Seixas da Cruz***, Edson José \\ Carpintero Rezende****, Thiago Carôso Fróes**, Camila Oliveira Freitas**, Paulo Cirino \\ Carvalho-Filho*****, Johelle de Santana Passos******, Eneida de Moraes Cerqueira*******, \\ Lília Ferreira de Moura-Costa****, Vera Costa Vale********, Roberto Meyer****
}

\footnotetext{
Corresponding author: Soraya Castro Trindade - soraya@uefs.br

* Laboratory of Immunology and Molecular Biology; Federal University of Bahia, Department of Health;

Feira de Santana State University, Bahia, Brazil

** Department of Health; Feira de Santana State University, Bahia, Brazil

*** Department of Health; Feira de Santana State University, Department of Epidemiology; Recôncavo da Bahia Federal University, Bahia, Brazil

**** Context and Validity Department, Minas Gerais State University, Minas Gerais, Brazil

***** Laboratory of Immunology and Molecular Biology; Federal University of Bahia, Bahia, Brazil

****** Department of Health; Feira de Santana State University, Department of Preventive Dentistry,

Federal University of Bahia, Bahia, Brazil

******** Department of Biological Sciences; Feira de Santana State University, Bahia, Brazil

********* Department of Microbiology; Bahia State University, Bahia, Brazi
}

\section{A B S T R A C T}

\begin{abstract}
AIMS: The aim of this study was to evaluate the presence of Porphyromonas gingivalis $(\mathrm{Pg})$ in the subgingival biofilm, as well as to compare the immune response of postpartum women and their newborns to Porphyromonas gingivalis using antibody serum levels.

METHODS: For this cross-sectional study, a total of 43 postpartum women and 24 newborns were selected in the municipal maternity hospital of Alagoinhas, Bahia, Brazil between February and December 2003, for this cross-sectional study. The presence of $\mathrm{Pg}$ was verified using polymerase chain reaction (PCR). The immunoglobulin serum levels: $\lg G 1, \lg G 2, \lg G 3, \lg G 4$ and $\lg A$, reactive to $P g$ ATCC 33277 were tested using Enzyme ImmunoAssay (ELISA).

RESULTS: $39,3 \%$ of the samples from postpartum women biofilm were positive for Pg. The incidence of this pathogen in women with periodontitis $(70 \%)$ was higher than in the group of women without disease $(30,30 \%)$. Among the newborns, high serum levels of IgG4 anti-Pg were observed $(p<0.001)$.

CONCLUSION: These findings confirm that postpartum women with periodontitis present remarkable incidence of Porphyromonas gingivalis which may influence systemic response, as represented by high levels of serum antibody levels against this pathogen in women and newborns. Furthermore, evidence suggests that some antibodies crossed the placental barrier in newborns.
\end{abstract}

Keywords: periodontitis, gingivitis, pregnancy, immunoglobulins. 
OBJETIVO: Avaliar a presença de Porphyromonas gingivalis $(\mathrm{Pg})$ no biofilme subgengival de puérperas e comparar a sua resposta imune e a de seus recém-nascidos contra este patógeno por meio dos níveis séricos de anticorpos.

MÉTODO: Para este estudo transversal, um total de 43 puérperas e 24 recém-nascidos foi selecionado na maternidade municipal da cidade de Alagoinhas, Bahia, Brazil entre fevereiro e dezembro de 2003. A presença de $\mathrm{Pg}$ foi verificada por meio da reação em cadeia da polimerase (PCR). Os níveis séricos das imunoglobulinas $\lg G 1$, $\lg G 2$, $\lg G 3$, $\lg G 4$ e $\lg A$, reativas a Pg ATCC33277, foram testados por imunoensaio enzimático (ELISA).

RESULTADOS: Foi observado que $39,3 \%$ das amostras de biofilme das puérperas foram positivas para Pg. A incidência do patógeno nas mulheres com periodontite $(70 \%)$ foi superior à encontrada no grupo de mulheres sem a doença $(30,30 \%)$. Entre os recém-nascidos, foram observados altos níveis séricos de $\lg G 4$ anti-Pg $(p<0.001)$.

CONCLUSÃO: Os achados confirmam que puérperas com periodontite apresentam uma alta incidência de Porphyromonas gingivalis, o que pode influenciar a resposta sistêmica, representada pelos altos níveis séricos de anticorpos contra este patógeno em mulheres e recém-nascidos. Além disso, as evidências sugerem que alguns anticorpos atravessam a barreira placentária, alcançando os recém-nascidos.

Palavras-chave: periodontite, gengivite, gravidez, imunoglobulinas 


\section{INTRODUCTION}

Indications of distant repercussions relating to periodontal disease can be seen to be a potential determinant for adverse gestational outcomes'. It is known that, in the relationship between bacterial aggression and host defense, a serie of reactions translated as local alterations takes place. All the indications are that distant alterations also occur.

Periodontal infection may serve as a chronic reservoir for microbial products that can affect other parts of the body through the blood circulation. Inflammatory mediators like $\mathrm{PGE}_{2}$ and tumor necrosis factor- $\alpha$ present increasing concentration during pregnancy, thereby reaching the critical levels that are needed for triggering delivery labor ${ }^{2}$. These mediators may be produced locally in the periodontium, in response to microbial challenge. Because of the high level of vascularization in periodontium, high levels of these substances may become established, thereby representing a systemic source of cytokines that are toxic to the fetus'.

Some studies ${ }^{3,4}$ found that periodontal and bacteriological conditions of pregnant women and the immunological profiles relating to periodontal disease are risk indicators in the relationship with adverse gestational outcomes. Other authors suggest that successful periodontal therapy in pregnant women with periodontitis is a protective factor promoting the birth of children with normal weight ${ }^{5}$. On the other hand, there are studies that do not corroborate this relationship $6,7,8,9,10$. One possible explanation for these divergent findings lies in the response of the organism to periodontal pathogenic bacteria, since this reflects an intricate network of events that is started by contact between the host's immune system and the bacteria ${ }^{11}$.

The high serum levels of antibodies against important periodontal pathogenic bacteria reflect the intensity of periodontal infection, for example by Porphyromonas gingivalis $(\mathrm{Pg})$. This anaerobic bacterium has been implicated as one of the most important agents of periodontal disease ${ }^{12}$. It can induce immune response profile imbalance, which switch to different isotypes of immunoglobulins, which can disturb the maternal-fetal balance.

Given the controversy surrounding this topic, the present pilot study sought to evaluate the presence of periodontal pathogens in the subgingival biofilm and the humoral immune response to sonicated extract of $\mathrm{Pg}$ from puerperae and to compare the serum levels of $\mathrm{Pg}$ antibodies between these women and their newborns.

\section{MATERIAL AND METHODS}

\section{Subjects}

Forty-three puerperae whose delivery had taken place at the municipal maternity hospital of Alagoinhas, Bahia, between February and December 2003, participated of this study. In 24 women, blood from the umbilical cord of their newborns had also been collected to evaluate the humoral immune response.

Exclusion criteria included diabetes, cardiovascular disease, or any other systemic disease that could alter the course of periodontal disease, pregnancy or immune response. Former smoking, previous consumption of systemic antimicrobials or antiinflammatory drugs (six or two months before, respectively), and periodontal therapy during the last twelve months also served as exclusion criteria. The eligible subjects were interviewed through a structured questionnaire to obtain sociodemographics, medical and lifestyle characteristics. The women's periodontal condition was evaluated by a single calibrated dentist (ECR; kappa 0.832). The probing depth of the sulcus/pocket, gingival recession or hyperplasia, clinical attachment loss and bleeding on probing were evaluated. These clinical parameters made it possible to determine each individual's periodontal condition 13. Post-partum women were considered to have periodontitis if they had four or more teeth with one or more sites presenting a probing depth greater than or equal to $4 \mathrm{~mm}$, a clinical attachment loss greater than or equal to $3 \mathrm{~mm}$, as well as bleeding on probing at the same site(s).

\section{Biofilm collection from post-partum women}

Samples of subgingival dental biofilm were collected from each site with the greatest probing depth in all sextants, using one sterile paper point (Dentsply, York, PA, USA) at each site, after drying and isolating the surrounding area using sterile gauze. Next, all six paper points from an individual's sextants were stored together in a single DNAse-free and RNAse-free microcentrifuge tube (Eppendorf) in a sterile solution of phosphate-buffered saline (PBS) 
at $-20^{\circ} \mathrm{C}$ until time of analysis.

\section{DNA extraction}

Bacterial DNA was extracted from the supernatant obtained by heating the tubes for $10 \mathrm{~min}$ at $100^{\circ} \mathrm{C}$, followed by thermal shock in an ice bath and centrifugation at $1300 \mathrm{rpm}$ for one minute [14]

\section{PCR for detection of bacterial DNA}

Amplification using the polymerase chain reaction (PCR) for detection of bacterial DNA was performed in volumes de $50 \mu \mathrm{l}$ containing $1 \mathrm{X} \mathrm{PCR} / \mathrm{Mg}++$ buffer (Boehringer Mannheim, Indianápolis, IN, USA), $0.2 \mathrm{mM}$ of dNTP (Pharmacia Biotech, Piscataway, NJ, USA), 0.5 U of Taq DNA polymerase (Boehringer Mannheim, Indianápolis, IN, USA), $0.4 \mu \mathrm{M}$ of each pair of primers and $10 \mathrm{ng}$ of the base. The amplification was performed in a thermocycler (Perkin Elmer, GeneAmp PCR System 2400, Norwalk, CT, USA), set at $94^{\circ} \mathrm{C}$ (five minutes) and accompanied by 30 cycles with a suitable annealing temperature for each pair of primers ${ }^{15}$. After 30 cycles, a temperature of $72^{\circ} \mathrm{C}$ was used for five minutes, for complete DNA extension. The amplification products were compared by means of electrophoresis on $1 \%$ agarose gel in 1XTBE buffer (1M Tris, 0.9M boric acid, 0.01M EDTA; pH 8.4) (Gibco BRL, Life Technologies Ltda, Bethesda, MD, USA), with ethidium bromide staining $(0.5 \mu \mathrm{g} / \mathrm{ml})$, and were photographed under a transilluminator with ultraviolet light (Kodak Digital Science System 120, Eastman Kodak Company, NY, USA). A standard of molecular mass $1 \mathrm{~kb}$ (kilobase) was included (Gibco BRL, Life Technologies Ltda, Bethesda, MD, USA).

\section{Blood Collection}

Samples of $5 \mathrm{ml}$ of blood were collected from antecubital fossa of the puerperae and from umbilical cord of the newborns, using tubes without anticoagulant (Vaccutainer, BD, Indianapolis, IN, USA), for subsequent centrifugation. The serum was collected and stored at $-20^{\circ} \mathrm{C}$.

\section{Immunological evaluation}

The levels of $\lg G$ subclass and $\lg A$ antibodies were evaluated using the Enzyme Linked Immunosorbent Assay (ELISA) method. High adsorption polystyrene plates (Costar, Cornig Life Science, Lowell, MA, USA) were sensitized with $10 \mu \mathrm{g} / \mathrm{ml}$ of protein from the sonicated extract of Porphyromonas gingivalis (ATCC 33277), diluted in 0.05M carbonate-bicarbonate buffer (pH 9.6). Diluted antigen was applied at the rate of $50 \mu \mathrm{l} /$ well and the plates were incubated for 15 hours at $4^{\circ} \mathrm{C}$, in a damp chamber. The washing buffer used at all stages of the tests was PBS, containing $0.05 \%$ Tween-20 detergent (PBS-T) and blocking was performed using a $2 \%$ BSA solution in STF-T at a rate of $200 \mu \mathrm{l} /$ well for two hours at $37^{\circ} \mathrm{C}$, in a damp chamber.

For each test, different dilutions of the serum in PBS containing $0.5 \%$ BSA were made: $1: 50(\operatorname{lgA}), 1: 500$ $(\lg G 1), 1: 100(\lg G 2), 1: 50 \quad(\lg G 3)$ and $1: 100$ (IgG4). The plates were incubated for one hour at $37^{\circ} \mathrm{C}$, in a damp chamber, and were then washed five times. The following immunoglobulin conjugates were added at the rate of $50 \mu \mathrm{l} /$ well: goat antihuman $\lg \mathrm{A}$ conjugated with peroxidase (Bethyl Laboratories, Montgomery, TX, USA), at a dilution of 1:50,000; mouse anti-human $\lg G 1$ conjugated with biotin (Southern Biotechnology Associates Inc., Birmingham, Al, USA), at a dilution of 1:2000; mouse anti-human IgG2 conjugated with biotin (Southern Biotechnology Associates Inc., Birmingham, Al, USA), at a dilution of 1:1000; mouse anti-human lgG3 conjugated with biotin (Southern Biotechnology Associates Inc., Birmingham, Al, USA), at a dilution of 1:2000; and mouse anti-human $\lg G 4$ conjugated with biotin (Southern Biotechnology Associates Inc., Birmingham, $\mathrm{Al}, \mathrm{USA}$ ), at a dilution of 1:1000. After incubation for one hour at $37^{\circ} \mathrm{C}$, the conjugates were discarded and the plates were washed five times with PBS-T.

To perform ELISA on the $\lg G$ subclasses, a signal amplification system using biotin-streptavidin was needed, thus adding a further step: incubation with streptavidin diluted in PBS at 1:7:500, followed by another five washes. The reactions were developed by means of $50 \mu \mathrm{l} /$ well of tetramethylbenzidine (TMB) developing solution (Zymed Laboratories, San Francisco, CA, USA), in accordance with the manufacturer's instructions. After incubation for 15 minutes at room temperature, shaded from bright light, the reactions were halted by adding $2 \mathrm{NH} 2 \mathrm{SO} 4$ at the rate of $25 \mathrm{\mu l} /$ well. Following this, the optical densities were measured using an ELISA reader (ELx 800; Bio Tek, Winooski, VT,USA) adjusted for wavelengths in the range from $450-630 \mathrm{~nm}$. The optical densities were corrected between plates for each type of standardized ELISA.

\section{Statistical Analysis}

Simple frequencies and central trend measurements 
were obtained regarding the socio-demographics, medical and lifestyle characteristics and statistical differences between groups were evaluated using the Chi-Square test for categorical variables and $t$ test for continuous variables, with a significance level of $5 \%$.

For comparisons between groups regarding the central trends of the data, the Mann-Whitney test was used. All the data analyses were performed using the Statistical Package for the Social Sciences (SPSS) software, version 17.0 for Windows.

\section{RESULTS AND DISCUSSION}

\section{Characterization of the subjects}

It was observed that there were no differences regarding the socio-demographics, medical and life style characteristics evaluated in this study among the groups: puerperae with periodontitis $(n=10 / 23.26 \%)$, and puerperae withoutperiodontitis $(n=33 / 76.74 \%)$. The age of participants ranged from 21 to 36 years old and it was composed mainly by low socio-economic level.

\section{Microbiological evaluation of the subgingival biofilm}

The microbiological data presented below relate to detection of periodontal pathogens in each puerperae examined, since the samples collected from six different sites were homogenized to reflect the individual's overall response. The results from PCR shown DNA fragments in agarosis gel: E.c.: Escherichia coli; P.g.: Porphyromonas gingivalis (Figure 1). It was demonstrated that the incidence of Porphyromonas gingivalis in the evaluated sample was $39.53 \%$. The incidence of $\mathrm{Pg}$ in ten postpartum women with periodontitis was remarkable: seven $(70 \%)$ were positive to the pathogen. In the group without periodontitis ten of 33 women showed Porphyromonas gingivalis in biofilm samples (30.30\%).

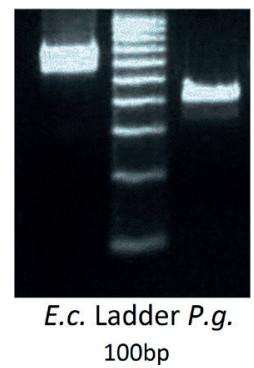

Figure 1: PCR for bacterial detection and identification.

\section{Evaluation of the humoral immune response of puerperae and newborns}

Prior quality control was performed on the ELISA tests by using the coordinates of ROC curves on data from healthy individuals and from individuals with periodontal disease without any systemic impairment (including in relation to pregnancy). From this, the cutoff point, sensitivity, specificity and positive and negative predictive values were established, as shown in Table 1.

Table 1: Quality control analysis on ELISA tests, by means of ROC curves.

\begin{tabular}{|c|c|c|c|c|c|}
\hline \multicolumn{3}{|c|}{ Immunoglobulin assay } & \multicolumn{2}{|r|}{ Positive } & \multirow{2}{*}{$\begin{array}{r}\text { Negative predictive } \\
\text { value }\end{array}$} \\
\hline assay & Sensitivity & Specifici & $\begin{array}{l}\text { ity } \\
\text { point }\end{array}$ & predctive value & \\
\hline $\lg A$ & 73.3 & 84.6 & 0.076 & $80.8 \%$ & $70.0 \%$ \\
\hline $\lg G$ & 82.8 & 80.8 & 0.206 & $82.8 \%$ & $80.8 \%$ \\
\hline $\lg G 1$ & 69.0 & 69.2 & 0.128 & $67.7 \%$ & $66.7 \%$ \\
\hline $\lg G 2$ & 62.1 & 57.7 & 0.186 & $67.7 \%$ & $66.7 \%$ \\
\hline $\lg G 3$ & 65.5 & 57.8 & 0.142 & $61.3 \%$ & $58.3 \%$ \\
\hline $\lg G 4$ & 93.1 & 76.9 & 0.198 & $81.8 \%$ & $90.9 \%$ \\
\hline
\end{tabular}


Anti-Porphyromonas gingivalis $\lg G 1$ levels were found to be low in both groups (Figure 2A), Puerperae had statistically significant higher lgG2 (Figure 2B) levels than newborns $(p<0.05)$. IgG3 levels were low in both groups (Figure 2C). IgG4 levels were found to be high in the serum of both the puerperae and their newborns (Figure 2D). Puerperae had statistically significant higher $\lg G$ total (Figure 2E) and $\operatorname{lgA}$ (Figure 2F) levels than newborns $(p<0.001)$.

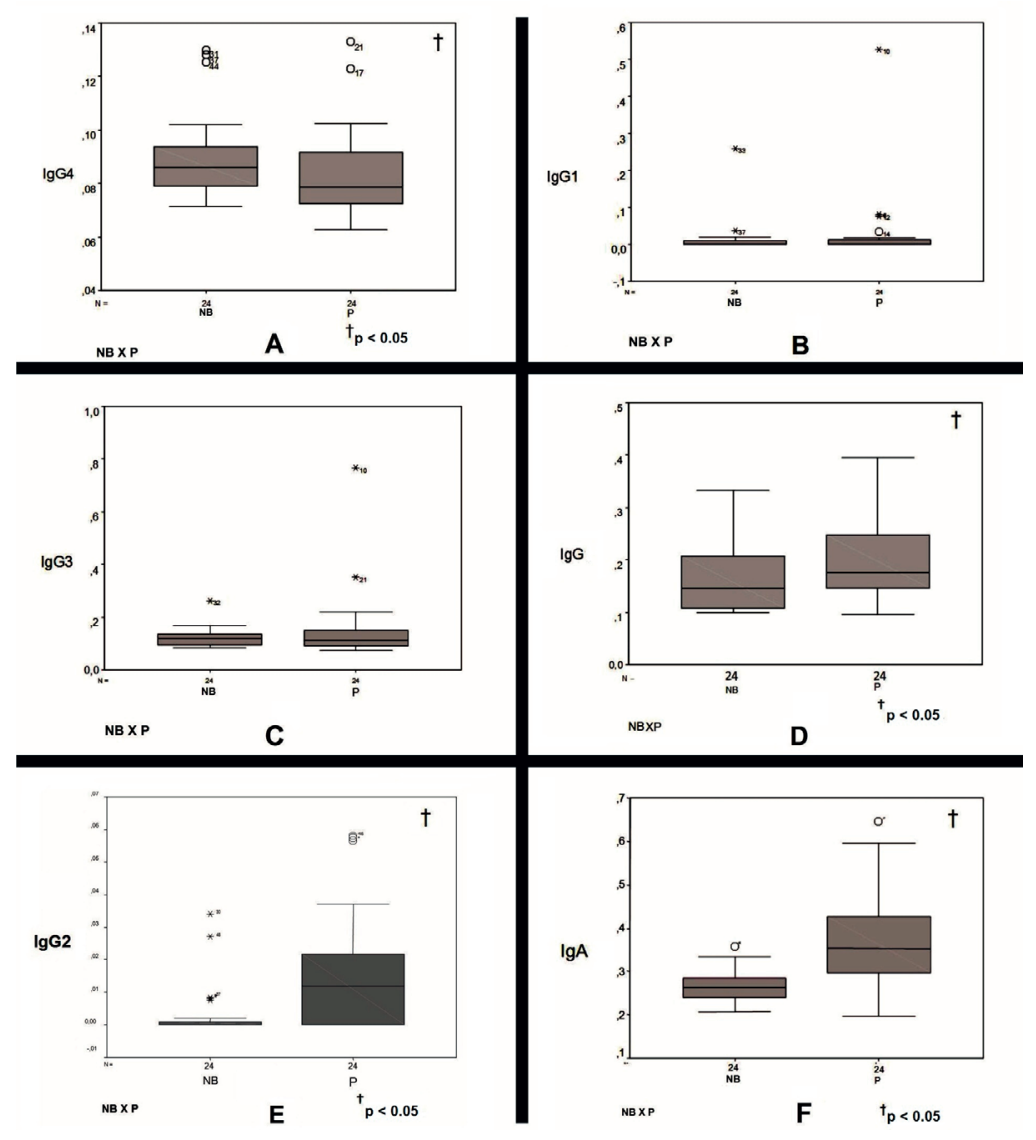

Figure 2: Serological reactivity among the postpartum women $(P)$ and newborns $(N B)$ against Porphyromonas gingivalis's antigens. $\nmid p<0.001$.

According to the analyses performed in the present pilot study, the occurrence of Porphyromonas gingivalis was high, mainly in the post-partum women with periodontitis when compared with ones without this disease. This was also found among others individuals with periodontitis, compared with individuals with a clinically health periodontium [15]. One likely explanation for the development of anaerobic microorganisms at sites in individuals with periodontitis may involve microenvironmental factors such as changes in redox potential in areas of periodontal pockets 18 and changes in hormone levels ${ }^{19,20}$. Even with the impossibility of quantifying the bacteria using the conventional PCR method for pathogen detection, the findings presented here corroborate results from realtime PCR for quantifying periodontal pathogens. For example, high prevalence of Actinobacillus actinomycetemcomitans, Porphyromonas gingivalis, Prevotella intermedia, Dialister pneumosintes, Campylobacter rectus and Micromonas micros were found in subgingival biofilm in 83 patients with periodontitis and 43 healthy volunteers ${ }^{15}$.

With regard to the humoral response of the puerperae and their newborns, another important finding was the high serum levels of anti-Porphyromonas gingivalis $\lg G 4$ in both groups. It is now known that transportation of $\lg G$ in humans begins around the twentieth week of pregnancy and that it increases progressively until delivery. Only antibodies in the IgG class cross the placental barrier, and the transmission rate of these immunoglobulins also varies according to the subclass to which they belong. $\lg G 1$ and $\operatorname{lgG} 3$ seem to cross the placenta slightly more efficiently than $\lg G 4$ does. In turn, the latter crosses the mother-fetus interface more efficiently than $\lg G 2$ 
does $^{21,22}$. It is possible that, through sensitization due to infection with Porphyromonas gingivalis, the puerperae of the present study produced and transmitted IgG4 to their babies, given that the fetus received antibodies against antigens to which their mothers were exposed previously.

On the other hand, the $\lg G 1$ and $\lg G 3$ levels were low among the puerperae and consequently among their newborns. Although it is known that individuals with periodontitis have higher serum levels of $\lg G 1$, while there is no difference in lg $G 3$ between different periodontal conditions ${ }^{21}$. However, out of the 43 puerperae studied in this investigation, only $23.25 \%$ presented periodontitis, thus probably explaining the low levels of $\lg G 1$ found among this group. As expected, the antibodies $\lg A$ and $\lg G 2$ were found at higher levels in the serum of the puerperae than in their newborns' serum. This confirms that, despite the high production in the puerperae, these immunoglobulins were not transmitted to the fetus. The evaluation of $\lg A$ and $\lg G 2$ in the present study was to understand the behavior of the humoral response of mothers which composed the sample.

It is important to note that the choice of $\mathrm{Pg}$ extract to assess the humoral response is due to its presence at high levels in periodontitis ${ }^{12}$. Furthermore, in puerperae evaluated in this study, the occurrence of this pathogen was high confirming this finding. Since this is a preliminary study, we chose to test only one extract, since future evaluations will be performed with different extracts of pathogens also prevalent. In this manner, and in the light of the initial evidence from the present pilot study, it is not the purpose of this investigation to relate the periodontal pathogens and antibody levels to adverse gestational complications, due to their preliminary results and limitations. But the findings of this study indicate that some $\lg G$ subclasses against Porphyromonas gingivalis crossed the placental barrier and the puerperae transmitted them to their babies. This can raise two opposing suppositions: in the first, a fetal passive immunization against Porphyromonas gingivalis to which the mother was exposed, regardless of having had the disease, can occurs. In the second, these immunological changes in the fetoplacental unit, stimulated by the presence of this periodontal pathogen can disrupt the immune profile balance, indicating that the relationship between periodontal disease and possible unfavorable gestational outcomes are likely. Thus, longitudinal studies evaluating the humoral response specific to
Porphyromonas gingivlis in pregnant women and the gestational outcomes are necessary to elucidate this relationship.

\section{CONCLUSION}

Continuation of this investigation may contribute important complementary information regarding the biological plausibility of the relationship between periodontal disease and possible unfavorable gestational outcomes.

\section{ACKNOWLEDGEMENTS}

To the Brazilian National Council for Scientific and Technological Development (CNPq), the Research Support Foundation of the State of Bahia (FAPESB) and Feira de Santana State University for financial support for the research. Thanks also to all the people who contributed with the scientific investigation.

\section{ETHICAL COMMITTEE APPROVAL}

All the participants asked, agreed to be enrolled in the study. The participants signed a statement of free and informed consent that had been approved by the Research Ethics Committee of Feira de Santana State University (protocols No 020/2002 and $114 / 2005$ ).

\section{REFERENCES}

1. Madianos PN, Bobetsis YA, Offenbacher

S. Adverse pregnancy outcomes (APOs) and periodontal disease: pathoenin mechaisms. J Clin Periodontol. 2013;40(Supp.14):S170-S180. doi: 10.1902/iop.2013.1340015. 
2. Sams N, Kornman K. Periodontitis and adverse pregnancy outcomes: consensus report of the joint EFP/AAP workshop on periodontitis and systemic diseases. J Clin Periodontol. 2013;40(Suppl. 14):S164-S169. doi: 10.1902/jop.2013.1340016.

3. Africa C, Kayitenkore J, Bayingana C. Examination of maternal gingival crevicular fluid for the presence of selected periodontipathogens implicated in the pre-term delivery of low birthweight infants. Virulence. 2010;1(4):254-9. doi: 10.4161 /viru.1.4.12004.

\section{Machado F, Cesar D, Assis A, Diniz C,} Ribeiro R. Detection and enumeration of periodontopathogenic bacteria in subgingival biofilm of pregnant women. Microbiology. 2012;26(5):443-9. doi: 10.1590/S180683242012000500011 .

\section{Gomes-Filho IS, Cruz SS, Costa Mda C,} Passos JS, Cerqueira EM, Sampaio FP, Pereira EC, Miranda LF. Periodontal therapy and low birth weight: preliminary results from an alternative methodologic strategy. J Periodontol. 2010;81:1725-33. Doi: DOI 10.1902/ jop.2010.100041.

6. Michalowicz BS, Hodges JS, Diangelis AJ, Lupo VR, Novak MJ, Ferguson JE, et al. Treatment of periodontal disease and the risk of preterm birth. N Engl J Med. 2006;355:1885-94.

7. Wimmer G, Pihlstrom BL. A critical assessment of adverse pregnancy outcome and periodontal disease. J Clin Periodontol. 2008;35:380-97. doi: $10.1111 /$ j.1600-051X.2008.01284.x.

8. Offenbacher S, Beck JD, Jared HL, Mauriello SM, Mendoza LC, Couper DJ, et al. Effects of periodontal therapy on rate of preterm delivery: a randomized controlled trial. Obstet Gynecol. 2009;1 14(3):551-9. doi: 10.1097/ AOG.0b013e3181b1341f.

9. Novak MJ, Novak KF, Hodges JS, Kirakodu S, Govindaswami $M$, Diangelis $A$, et al. Periodontal bacterial profiles in pregnant women: response to treatment and associations with birth outcomes in the obstetrics and periodontal therapy (OPT) study. J Periodontol. 2008;79(10):1870-9. doi: 10.1902/ jop.2008.070554.

10. Ebersole JL, Novak MJ, Michalowicz BS, Hodges JS, Steffen MJ, Ferguson JE, et al. Systemic immune responses in pregnancy and periodontitis: relationship to pregnancy outcomes in the Obstetrics and Periodontal Therapy (OPT) study. J Periodontol. 2009;80(6):953-60. doi: 10.1902/ jop.2009.080464.

11. Kurdowska AK, Noble JM, Adcock JE. Interleukin- 8 and anti-interleukin- 8 autoantibodies in gingival crevicular fluid from patients with periodontitis. J Periodontal Res. 2003;38(1):73-8. doi: 10.1034/i.1600-0765.2003.02001.x.

12. Ezzo PJ, Cutler CW. Microorganisms as risk indicators for periodontal disease. Periodontol 2000. 2003;32:24-35. DOI: 10.1046/i.0906$6713.2003 .03203 . x$.

\section{Gomes-Filho IS, Cruz SS, Rezende EJ, Dos} Santos CA, Soledade KR, Magalhaes MA, et al. Exposure measurement in the association between periodontal disease and prematurity/low birth weight. J Clin Periodontol. 2007;34(1 1):957-63. doi: $10.1111 /$ j.1600-051X.2007.01141.x.

\section{Ashimoto A, Chen C, Bakker I, Slots J.}

Polymerase chain reaction detection of 8 putative periodontal pathogens in subgingival plaque of gingivitis and advanced periodontitis lesions. Oral Microbiol Immunol. 1996; 1 1(4):266-73. doi: $10.1111 /$ i.1399-302X.1996.tb00180.x.

15. Nonnenmacher C, Dalpke A, Rochon J, FloresDe-Jacoby L, Mutters R, Heeg, K. Real-time polymerase chain reaction for detection and quantification of bacteria in periodontal patients. Journal of Periodontology. 2005;76(9):1542-9. doi: 10.1902/jop.2005.76.9.1542

16. Teng HC, Lee $\mathrm{CH}$, Hung HC, Tsai CC, Chang YY, Yang $\mathrm{YH}$, et al. Lifestyle and psychosocial factors associated with chronic periodontitis in Taiwanese adults. J Periodontol. 2003;74(8): 1 169-75. doi: 10.1902/jop.2003.74.8.1169.

17. Preshaw PM, Seymour RA, Heasman PA. Current concepts in periodontal pathogenesis. Dent Update. 2004;31(10):570-2,74-8. 
18. Kenney EB, Ash MM Jr. Oxidation reduction potential of developing plaque, periodontal pockets and gingival sulci. J Periodontol. 1969;40(11):630-3. doi: 10.1902/ jop.1969.40.1 1.630.

19. Eleni $M$, Boura $E$, Tsalikis L, Konstantinides A. The influence of sex steroid hormones on gingiva of women. Open Dent J. 2009;3:1 14-9. doi: $10.2174 / 1874210600903010114$.

20. Klinger G, Eick S, Pfister W, Graser T, Moore $C$, Oettel M. Influence of hormonal contraceptives on microbial flora of gingival sulcus. Contraception. 1998;57(6):381-4. doi: 10.1016/S00107824(98)00044-4.

21. Trindade SC, Gomes-Filho IS, Meyer RJ, Vale VC, Pugliese L, Freire SM. Serum antibody levels against Porphyromonas gingivalis extract and its chromatographic fraction in chronic and aggressive periodontitis. J Int Acad Periodontol. 2008; 10(2):50-8. 